http://ojs.umrah.ac.id/index.php/kiprah/index

\title{
Identifikasi Miskonsepsi Mahasiswa pada Konsep Evolusi Menggunakan Certainty of Response Index (CRI)
}

\author{
Azza Nuzullah Putri", Nur Eka Kusuma Hindrasti \\ Pendidikan Biologi, Universitas Maritim Raja Ali Haji, Tanjungpinang, Kepulauan Riau, Indonesia \\ Pengiriman: 14/11/2019; Diterima: 26/06/2020; Publikasi: 30/06/2020 \\ DOI: https://doi.org/10.31629/kiprah.v8i1.1604
}

\begin{abstract}
Abstrak
Miskonsepsi merupakan adanya ketidaksesuaian antara konsep yang dimiliki mahasiswa dengan yang dimiliki oleh ahli. Kesalahan dalam pemahaman konsep oleh mahasiswa memiliki dampak yang tidak sedikit dalam proses dan hasil belajar. Beberapa konsep dalam biologi seperti konsep-konsep yang berkaitan dengan evolusi sering terjadi kesalahan dalam memahaminya. Teori-teori dalam evolusi merupakan salah satu subkonsep evolusi yang sering terdapat perbedaan dan perdebatan. Hal ini menimbulkan berbagai persepsi bagi mahasiswa sehingga tidak jarang banyak yang salah dalam memahaminya. Untuk menganalisis terjadi miskonsepsi pada mahasiswa, digunakan metode Certainty of Response Index (CRI). Instrumen ini berupa tes yang dilengkapi dengan tingkat keyakinan dalam menjawabnya. Analisis miskonsepsi menggunakan CRI dilakukan untuk mengetahui tingkat pemahaman dan miskonsepsi yang dialami mahasiswa, kemudian juga untuk mengidentifikasi pada subkonsep apa saja miskonsepsi tersebut terjadi. Data diperoleh menggunakan instrumen tes miskonsepsi berupa soal pilihan ganda yang dilengkapi tingkat keyakinan. Penelitian dilakukan pada 42 orang mahasiswa yang mengambil matakuliah evolusi semester genap 2018/2019. Berdasarkan hasil tes yang dilakukan dan analisis menggunakan CRI diperoleh sebaran rata-rata tingkat pemahaman mahasiswa. Hasil sebaran tersebut yaitu paham konsep 24,27\%, menebak 4,1, tidak paham konsep 17,13\% dan miskonsepsi $58,33 \%$. subkonsep mekanisme evolusi menjadi subkonsep yang paling banyak terjadi miskonsepsi yaitu sebanyak 73,81\%, sedangkan yang paling sedikit terjadi pada subkonsep evolusi plantae dan animalia $42,86 \%$. Agar proses identifikasi miskonsepsi dapat dilakukan dengan lebih spesifik dan akurat maka diperlukan kombinasi teknik lainnya di samping penggunaan tes dalam melakukan analisis miskonsepsi lebih lanjut.
\end{abstract}

Kata kunci: miskonsepsi; konsep evolusi; certainty of response index (CRI)

\begin{abstract}
The misconception is a mismatch between the concepts students have and those possessed by experts. Misunderstanding of the concept having an impact on the student learning process and outcomes. Some concepts on biology such as evolution concepts frequent mistakes in understanding. Theories in evolution are one of the commonest subconcepts differences and debates. This raises a variety of perceptions for students so that not infrequently many are wrong in understanding it. Misconception analysis is performed using the certainty of the response index method. Test that is equipped with a level of confidence in answering it. Misconception analysis using CRI was conducted to determine the level of understanding and misconception experienced by students. Then also to identify what sub-concepts the misconception has occurred. Data was collected through a misconception test instrument on 42 students who took the evolution semester course even 2018/2019. Based on the results of the test conducted and analysis using CRI obtained an average distribution of students' level of understanding. The results of the distribution are understanding the concept of $24.27 \%$, guessing 4.1, not understanding the concept of $17.13 \%$, and misconception $58.33 \%$. The sub-concept of the mechanism of evolution is the most common sub-concept of misconception is $73.81 \%$. While the least misconceptions occurred in the evolution of Plantae and Animalia sub-concepts $42.86 \%$. So that the process of
\end{abstract}


identifying misconceptions can be done more specifically and accurately, we need a combination of other techniques besides the use of tests in carrying out further misconceptions analysis.

Keywords: misconception; evolution concept; certainty of response index (CRI)

\section{PENDAHULUAN}

Pada pembelajaran IPA termasuk salah satunya Biologi, kita sangat mudah menemukan terjadinya miskonsepsi. Miskonsepsi merupakan ketidaksesuaian antara konsep yang dimiliki peserta didik dengan yang dimiliki oleh ahli. Miskonsepsi bisa muncul pada peserta didik yang diperoleh dari interaksinya dalam kehidupan sehari-hari. Berdasarkan pengalaman yang dimilikinya, kemudian dapat terbentuk konsep mengenai pengalaman tersebut. Konsep yang telah terbentuk itu belum dapat digolongkan pada sesuatu yang benar. Namun, jika konsep yang telah terbentuk salah maka tidak mudah untuk memperbaikinya. Kesalahan dalam pemahaman konsep oleh mahasiswa memiliki dampak yang tidak sedikit dalam proses dan hasil belajar. Sesuai dengan hasil penelitian yang disampaikan oleh Antika \& Ibana (2018) yang menunjukkan bahwa adanya korelasi yang siginifikan antara identifikasi miskonsepsi dengan hasil belajar.

Pada pembelajaran biologi, peserta didik akan dihadapkan pada berbagai konsep-konsep yang memiliki beragam tingkat kesulitan, sehingga tidak jarang baik guru maupun peserta didik sering mengalami kesalahan dalam memahaminya. Beberapa penelitian sebelumnya telah mengidentifikasi berbagai miskonsepsi yang terjadi dalam memahami konsep-konsep biologi. Identifikasi yang telah dilakukan Chaniarosi (2014) menyebutkan bahwa guru Biologi mengalami miskonsepsi pada beberapa subkonsep materi sistem reproduksi manusia. Begitu juga dengan hasil penelitian Hala, Syahdan, et.al (2018) menemukan miskonsepsi dialami guru biologi dalam memahami konsep sel. Di samping itu, miskonsepsi juga dialami peserta didik dalam memahami berbagai konsep biologi seperti pada konsep fotosintesis dan respirasi tumbuhan (Mustaqim, et.al, 2015; Setiawati, 2019), konsep materi archaebacteria dan eubacteria (Dwijayanti et al., 2016; Kurniasih \& Haka, 2017), dan konsep genetika (Murni, 2013; Mustika, Hala, \& Arsal, 2014). Hal ini tentunya tidak menutup kemungkinan bahwa miskonsepsi juga terjadi pada konsep-konsep biologi lainnya, seperti konsep evolusi.

Evolusi sebagai bagian dari cabang ilmu biologi, memiliki berbagai konsep penting yang sangat terkait dengan berbagai kajian ilmu lainnya seperti, genetika, anatomin, morfologi, paleontologi, zoologi, botani, geologi, dan lainnya. Hal ini menjadikan konsep-konsep dalam evolusi cukup kompleks untuk dapat dipahami. Teori-teori dalam evolusi merupakan salah satu bagian subkonsep yang memiliki banyak perbedaan dan sering menimbulkan perdebatan di dalamnya. Hal ini dapat berpotensi memunculkan berbagai persepsi bagi mahasiswa sehingga tidak jarang banyak yang salah dalam memahami konsep-konsep pada evolusi. Infanti \& Wiles (2011) mneyebutkan bahwa pemahaman dan sikap siswa terhadap relevansi evolusi dengan penelitian dan penemuan ilmiah, serta kehidupan sehari-hari mereka, sangat penting. Mampu menghubungkan konsep evolusi dengan masalah ilmiah adalah keterampilan mendasar bagi setiap siswa biologi.

Oleh karena itu, agar dapat mengidentifikasi tingkat pemahaman mahasiswa serta miskonsepsi yang terjadi pada konsep evolusi ini, perlu dilakukan analisis lebih lanjut. Analisis ini penting dilakukan agar miskonsepsi yang terjadi pada mahasiswa dapat segera dideteksi sehingga dapat diberikan solusi yang sesuai (Astuti, Redjeki, \& Nurhayati, 2016). Miskonsepsi akan dapat menghambat proses penerimaan dan asimilasi pengetahuanpengetahuan baru dalam diri peserta didik, sehingga dapat menghalangi keberhasilan 
dalam pembelajaran berikutnya jika tidak segera diatasi (Klammer, 1998). Salah satu metode untuk menganalisis miskonsepsi ini adalah dengan menggunakan Metode Certainty of Response Index (CRI).

Metode CRI ini dikembangkan untuk dapat mengidentifikasi terjadinya miskonsepsi pada peserta didik sekaligus juga untuk mendeteksi kelompok peserta didik yang tidak paham konsep. Hasil penggunaan CRI pada beberapa penelitian identifikasi miskonsepsi menunjukkan bahwa penggunaan CRI cukup efektif untuk dapat membedakan para peserta didik yang mengalami miskonsepsi serta peserta didik yang tidak tahu konsep (Haris, 2013; Murni, 2013; Tayubi, 2005). Instrumen penelitian yang dirancang dengan baik, dapat nantinya digunakan untuk mengidentifikasi konsepsi-konsepsi yang menjadi miskonsepsi pada diri peserta didik.

Pada metode ini, soal yang digunakan adalah soal tes pilihan ganda yang dilengkapi dengan tingkat keyakinan (CRI). Pada hasil CRI yang rendah, hal ini menunjukkan bahwa peserta didik melakukan guessing, jika nilai CRI tinggi maka menunjukkan peserta didik menjawab dengan tingkat kepercayaan tinggi pada jawaban yang telah dipilihnya. Pada keadaan ini, jika jawaban peserta didik benar, artinya memiliki tingkat keyakinan tinggi terhadap kebenaran konsepnya telah teruji (justified) dengan baik. Namun, sebaliknya, jika jawaban responden salah, hal tersebut dapat menjadi sebuah indicator telah terjadinya miskonsepsi.

Dengan metode ini, peneliti mengembangkan instrumen tes yang dilengkapi dengan tingkat keyakinan atau kepastian peserta didik dalam menjawab soal yang diberikan. Sehingga berdasarkan hasil analisis CRI akan diketahui tingkat pemahaman dan miskonsepsi yang dialami mahasiswa dan pada subkonsep apa saja miskonsepsi tersebut dialami.

\section{METODE PENELITIAN}

Penelitian ini merupakan penelitian deskriptif kuantitatif yang bertujuan untuk mengidenifikasi miskonsepsi mahasiswa pada konsep evolusi. Penelitian dilakukan pada mahasiswa pendidikan biologi Universitas
Maritim Raja Ali Haji yang mengikuti perkuliahan pada semester genap 2018/2019 sebanyak 42 orang mahasiswa.

Data dikumpulkan menggunakan instrumen tes miskonsepsi berupa soal pilihan ganda sebanyak sepuluh butir soal yang dilengkapi pilihan tingkat keyakinan (menggunakan CRI) dalam menjawab soal tersebut. CRI yang digunakan yaitu berskala 4 seperti yang ditunjukkan pada tabel 1 . Hasil yang diperoleh kemudian dianalisis menggunakan metode certainty response index (CRI). Instrumen soal yang digunakan dikembangkan berdasarkan beberapa indikator yang mencakup beberapa subkonsep pada konsep evolusi yaitu teoriteori evolusi, mekanisme evolusi serta evolusi plantae, dan animalia.

Pada pengolahan data dilakukan pengelompokkan pemahaman siswa dalam empat kelompok yaitu; paham konsep, menebak (lucky guess), tidak paham konsep, dan mengalami miskonsepsi. Selain pengelompokkan data kemudian juga diidentifikasi dan analisis bagian subkonsep apa saja pada konsep evolusi yang mengalami miskonsepsi.

Tabel 1. Kategori Keyakinan Jawaban Menggunakan Metode CRI Skala 4 dan Kriterianya

\begin{tabular}{cc}
\hline CRI & Kriteria \\
\hline 1 & $\begin{array}{c}\text { Sangat tidak yakin (Almost } \\
\text { guess) }\end{array}$ \\
\hline 2 & Tidak yakin (Not sure) \\
\hline 3 & Yakin (Sure) \\
\hline 4 & Sangat yakin (Almost certain) \\
\hline
\end{tabular}

Sumber: (Nursiwin \& Hairida, 2014)

Tabel 2. Matriks Pedoman Jawaban Berdasarkan Nilai CRI.

\begin{tabular}{lll}
\hline \multicolumn{1}{c}{ Kriteria } & \multicolumn{1}{c}{$\begin{array}{c}\text { CRI Rendah } \\
(<2,5)\end{array}$} & \multicolumn{1}{c}{$\begin{array}{c}\text { CRI Tinggi } \\
(>2,5)\end{array}$} \\
\hline Jawaban & Jawaban benar & Jawaban benar \\
benar & $\begin{array}{l}\text { tetapi CRI } \\
\text { rendah berarti }\end{array}$ & $\begin{array}{l}\text { dan CRI tinggi } \\
\text { berarti }\end{array}$ \\
& tidak tahu & menguasai \\
& konsep (Lucky & konsep \\
& guess) & dengan baik \\
\hline
\end{tabular}




\begin{tabular}{lll}
\hline Jawaban & Jawaban salah & Jawaban salah \\
salah & dan CRI & tetapi CRI \\
& rendah berarti & tinggi berarti \\
& tidak tahu & terjadi \\
& konsep & miskonsepsi \\
\hline
\end{tabular}

Sumber: (Hasan, Bagayoko, \& Kelley, 1999)

\section{HASIL DAN PEMBAHASAN}

Tabel 3. Sebaran Persentase Rata-rata Kelompok Pemahaman Mahasiswa

\begin{tabular}{ccc}
\hline No & Kelompok pemahaman & $\begin{array}{c}\text { Persentase Rata- } \\
\text { rata }\end{array}$ \\
\hline 1 & Paham konsep & 24.27 \\
\hline 2 & Menebak & 4.1 \\
\hline 3 & Tidak tahu konsep & 17.13 \\
\hline 4 & Miskonsepsi & 58.33 \\
\hline
\end{tabular}

Berdasarkan Tabel 3 diketahui bahwa sebagian mahasiswa mengalami miskonsepsi dan hanya sebagian kecil yang paham konsep. Sedangkan sisanya merupakan kelompok tidak tahu konsep dan lucky guess atau menebak.

Tabel 4. Persentase Rata-rata Miskonsepsi Pada Subkonsep Evolusi

\begin{tabular}{ccc}
\hline No & Subkonsep & $\begin{array}{c}\text { Persentase rata- } \\
\text { rata }\end{array}$ \\
\hline 1 & Teori Evolusi & 58.33 \\
\hline 2 & Mekanisme Evolusi & 73.81 \\
\hline 3 & $\begin{array}{c}\text { Evolusi Plantae dan } \\
\text { Animalia }\end{array}$ & 42.06 \\
\hline
\end{tabular}

Pada tabel 4. di atas, diketahui bahwa miskonsepsi paling tinggi yaitu pada subkonsep evolusi plantae dan animalia. Artinya hampir keseluruhan mahasiswa mengalami miskonsepsi pada tiap subkonsep evolusi. Miskonsepsi paling banyak terjadi pada subkonsep mekanisme evolusi, kemudian subkonsep teori evolusi dan paling sedikit pada subkonsep evolusi plantae dan animalia. Pada gambar 1., diketahui bahwa dari keempat kelompok pemahaman mahasiswa pada konsep evolusi bagian menebak paling sedikit dilakukan oleh mahasiswa pada seluruh subkonsep.

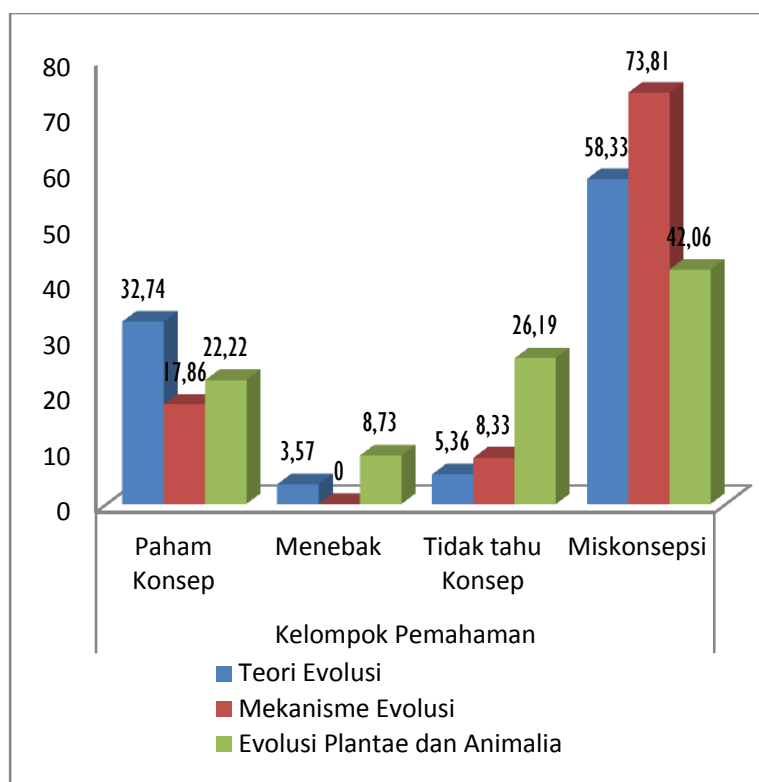

Gambar 1 Diagram Sebaran Kelompok

Pemahaman Berdasarkan Subkonsep pada Evolusi

Pada subkonsep mekanisme evolusi berisi tentang konsep-konsep penting yang menjelaskan bagaimana proses evolusi dapat terjadi. Beberapa konsep yang dibahas adalah mengenai konsep seleksi alam, mutasi, rekombinasi seksual, gene flow, dan genetic drift. Kemungkinan terjadinya miskonsepsi pada konsep tersebut cukup besar terutama pada penjelasan dan pemberian contoh mekanisme gene flow dan genetic drift. Mahasiswa masih banyak yang ragu dalam mengidentifikasi contoh proses evolusi yang terjadinya melalui mekanisme tersebut. Hal ini juga disampaikan oleh Pazza, Penteado, \& Kavalco (2010) dalam penelitiannya menyatakan bahwa beberapa konsep evolusi terkait dengan the evidence for evolution, the role of natural selection dan random events, as well as the sources of variation, harus lebih difokuskan dalam pembelajaran evolusi.

Pada subkonsep teori evolusi, sebagian mahasiswa juga mengalami miskonsepsi, sedangkan sebagian lainnya termasuk telah paham konsep, sebagian kecil lainnya termasuk tidak paham konsep dan menebak. Subkonsep ini membahas berbagai teroi-teori dari para ahli yang terkait dengan evolusi. Sebagian besar teori evolusi telah 
sering dipelajari dan dibahas pada tingkat sekolah menengah, sehingga pada saat perkuliahan pembahasan teori ini sudah tidak asing lagi bagi mahasiswa. Hanya saja masih ada kesalahankesalahan dalam memahami isi teori terkait evolusi yang dibutuhkan bimbingan dan arahan dari dosen. Pada subkonsep ini, mahasiswa yang memahami konsep lebih banyak dibandingkan pada subkonsep lainnya.

Evolusi plantae dan animalia menjadi subkonsep dengan minskonsepsi yang paling sedikit dibandingkan subkonsep lainnya. Subkonsep ini membahas tentang perkembangan evolusi pada tumbuhan dan Animalia khususnya vertebrata. Sebagian besar materi ini telah mencakup pembahasan yang terkait pada mata kuliah taksonomi, morfologi, anatomi, dan genetika yang telah dipelajari sebelumnya. Pembahasan pada evolusi sangat berkaitan dengan pembahasan pada cabang ilmu biologi dan IPA lainnya, sehingga pada saat memahami konsepkonsep pada bagian ini tidak terlalu menjadi masalah bagi mahasiswa. Hal ini disebabkan konsep yang diperoleh merupakan penambahan dari konsep yang telah ada sebelumnya. Jika konsep sebelumnya telah dipahami dengan baik maka untuk berpindah ke konsep berikutnya akan lebih terbantu. Hal ini terlihat pada hasil bahwa berdasarkan tes yang dilakukan pada subkonsep ini tidak terlalu banyak yang mengalami miskonsepsi dibandingkan subkonsep lainnya.

Hasil penelitian keseluruhan menunjukkan bahwa mahasiswa yang paham konsep masih sedikit atau kurang dari setengah mahasiswa yang mengikuti perkuliahan evolusi tersebut yaitu hanya berkisar pada 17\%-33\%. Salah satu penyebab rendahnya pemahaman konsep evolusi diakibatkan oleh tingginya miskonsepsi dan lack of knowledge. Hal tersebut dipengaruhi oleh beberapa faktor baik faktor dalam ataupun faktor luar.

Salah satu faktor dalam yang memengaruhinya yaitu disebabkan dari ketidakmampuan siswa dalam mengembangkan pemahaman terhadapat konsep-konsep dengan tingkat kesulitan yang lebih tinggi daripada sebelumnya. Selain itu, mahasiswa juga kurang mampu dalam menghubungkan antara konsepkonsep dasar dengan konsep-konsep dengan tingkat kesulitan yang lebih tinggi. Hal ini dapat dikarenakan karena keterbatasan dari kognitif mahasiswa sendiri. Faktor psikologis yang berasal dari dalam diri mahasiswa juga akan memberikan pengaruh bagi mahasiswa dalam memahami suatu konsep.

Selain faktor dalam, faktor luar juga dapat memberikan pengaruhnya, seperti yaitu ketersediaan fasilitas dan sumber belajar yang mendukung pengembangan pemahaman siswa, metode atau cara guru dalam menyampaikan pembelajaran, lingkungan belajar siswa serta faktor lainnya. Hasil penelitian Mustika et al. (2014) menyebutkan bahwa salah satu faktor penyebab terjadinya miskonsepsi disebabkan oleh penalaran mahasiswa yang salah akibat tidak lengkapnya informasi mengenai suatu konsep yang diterima oleh mahasiswa.

Beberapa penyebab terjadinya miskonsepsi juga dapat dikarenakan karena kurang kemampuan dalam melakukan penalaran oleh mahasiswa, hal ini sejalan dengan penelitian yang dilakukan Hala et.al (2018) yang menyatakan bahwa miskonsepsi dikarenakan oleh rendahnya kemampuan penalaran, kurangnya sumber belajar yang berfungsi yang dijadikan sebagai referensi serta juga dikarenakan terdapat banyak istilah asing dalam konsep tersebut. Konsep evolusi sendiri memiliki karakteristik materimateri yang bersifat kompleks karena konsep-konsep evolusi sudah merupakan sintesis dari berbagai kajian ilmu. Hal ini menjadikan konsep-konsep evolusi cukup sulit bagi mahasiswa, dengan demikian sangat rentan untuk terjadinya kesalahan dalam memahaminya.

Penelitian ini penggunaan metode CRI terbatas hanya dapat mengidentifikasi sebaran kelompok pemahaman mahasiswa, apakah termasuk kelompok miskonsepsi, paham konsep, menebak atau kelompok yang tidak paham konsep. Tes diagnostik dengan menggunakan CRI bisa digunakan dengan mudah untuk membedakan mahasiswa yang mengalami miskonsepsi 
dengan yang lack of knowledge dengan baik (Hasan et al., 1999), namun tes ini belum dapat mengungkap proses penalaran mahasiswa dan penyebab terjadinya miskonsepsi secara spesifik. Oleh karena itu, untuk dapat melakukan diagnosis lebih lanjut maka penggunaan tes dapat dikombinasikan dengan teknik lain yang mendukung identifikasi penyebab miskonsepsi lebih lanjut seperti yang dilakukan (Septiana, Zulfiani, 2015; Murni, 2013) yaitu dengan menggunakan kombinasi tes diagnostik beralasan dilengkapi wawancara (two-tier diagnostic) untuk dapat mengetahui miskonsepsi mahasiswa.

\section{KESIMPULAN}

Berdasarkan hasil tes yang dilakukan dan dianalisis menggunakan CRI didapatkan bahwa sebagian besar mahasiswa mengalami miskonsepsi. Miskonsepsi terjadi pada ketiga subkonsep yaitu teorie evolusi, mekanisme evolusi serta evolusi plantae dan animalia. Miskonsepsi paling banyak ditemui pada subkonsep mekanisme evolusi dan yang paling sedikit pada subkonsep evolusi plantae dan animalia. Penggunaan metode CRI dapat digunakan untuk membedakan kelompok antara mahasiswa yang mengalami miskonsepsi dengan mahasiswa yang lack of knowledge dengan baik namun belum dapat menjelaskan proses penalaran serta penyebab miskonsepsi secara spesifik yang terjadi pada mahasiswa. Agar miskonsepsi dapat diidentifikasi dengan lebih spesifik dan akurat maka diperlukan kombinasi teknik lainnya disamping penggunaan tes dalam melakukan analisis miskonsepsi lebih lanjut.

\section{UCAPAN TERIMA KASIH}

Artikel yang disusun merupakan hasil publikasi penelitian menggunakan skema Penelitian Dosen Muda Tahun 2019 yang didanai dari DIPA UMRAH. Penulis ucapkan terimakasih kepada para pimpinan Universitas Maritim Raja Ali Haji atas segala dukungan pendanaannya dalam menyelesaikan penelitian ini.

\section{REFERENSI}

Antika, L. T., \& Ibana, L. (2018). Perbandingan
Korelasi Identifikasi Miskonsepsi Teori Evolusi dengan Hasil Belajar Mahasiswa Pendidikan Fisika dan Biologi. Jurnal Pendidikan Biologi, 3(2), $1-8$. https://doi.org/http://dx.doi.org/10.3193 2/ JPBIO (Jurnal Pendidikan Biologi)

Astuti, F., Redjeki, T., \& Nurhayati, N. (2016). Identifikasi Miskonsepsi dan Penyebabnya Pada Siswa Kelas XI MIA SMA Negeri 1 Sukoharjo Tahun Pelajaran 2015/2016 Pada Materi Pokok Stoikiometri. Jurnal Pendidikan Kimia Universitas Sebelas Maret, 5(2), 10-17.

Chaniarosi, L. F. (2014). Identifikasi Miskonsepsi Guru Biologi SMA Kelas XI IPA Pada Konsep Sistem Reproduksi Manusia. 2(1998), 187191.

Septiana, D. \& Zulfiani, M. F. N. (2015). Identifikasi Miskonsepsi Siswa Pada Konsep Archaebacteria Dan Eubacteria Menggunakan Two-Tier Multiple Choice. Edusains, 6(2), 191-200. https://doi.org/10.15408/es.v6i2.1151

Dwijayanti, A., Muniyatie, S., \& Rakhmawati, A. (2016). Analisis miskonsepsi archaebacteria dan eubacteria dalam buku biologi sma kelas x di kabupaten sleman. Jurnal Pendidikan Biologi, 5(8), 32-42.

Hala, Y., Syahdan, U. A., Pagarra, H., \& Saenab, S. (2018). Identification of Misconceptions on Cell Concepts among Biology Teachers by Using CRI Method. Journal of Physics: Conference Series, 1028(1). https://doi.org/10.1088/1742$6596 / 1028 / 1 / 012025$

Haris, V. (2013). Identifikasi Miskonsepsi Materi Mekanika dengan Menggunakan CRI ( Certainty of Response Index ). Jurnal Ta'dib, 16(1), 77-86.

Hasan, S., Bagayoko, D., \& Kelley, E. L. (1999). Misconceptions and the Certainty of Response Index (CRI). 
Physics Education, 34(5), 294-299. https://doi.org/10.1088/0031-9120/34/5/304

Infanti, L. M., \& Wiles, J. R. (2011). "Evo in the News:" Understanding Evolution and Students' Attitudes Toward the Relevance of Evolutionary Biology. 9-14.

Klammer, J. (1998). An Overview of Techniques for Identifying , Acknowledging and Overcoming Alternate Conceptions in Physics Education. Klingenstein Project Report, Teachers College-Columbia University.

Kurniasih, N., \& Haka, N. B. (2017). Penggunaan Tes Diagnostik Two-Tier Multiple Choice Untuk Menganalisis Miskonsepsi Siswa Kelas X Pada Materi Archaebacteria Dan Eubacteria. Biosfer: Jurnal Tadris Biologi, $8(1)$, 114-127. https://doi.org/10.24042/biosf.v8i1.1270

Murni, D. (2013). Identifikasi Miskonsepsi Mahasiswa Pada Konsep Substansi Genetika Menggunakan Certainty of Response Index (CRI). Prosiding Semirata FMIPA Universitas Lampung, 205-212.

Mustaqim, Ade, T., Zulfiani, Y. H. (2015). Identifikasi Miskonsepsi Siswa Dengan Menggunakan Metode Certainty of Response Index (CRI) Pada Konsep Fotosintesis dan Respirasi Tumbuhan. Edusains, 6(2), 145152. https://doi.org/10.15408/es.v6i2.1117

Mustika, A. A., Hala, Y., \& Arsal, A. F. (2014). Negeri Makassar pada Konsep Genetika dengan Metode CRI Identification of Misconception of Biology Students at State
University of Makassar on Genetic Concept by Applying CRI Method. Jurnal Sainsmat, III(2), 122-129.

Nursiwin, Hairida, I. (2014). Menggali Miskonsepsi Siswa SMA Pada Materi Perhitungan Kimia Menggunakan Certainty of Response Index. Jurnal Pendidikan Dan Pembelajaran Khatulistiwa, 3(1).

Pazza, R., Penteado, P. R., \& Kavalco, K. F. (2010). Misconceptions about Evolution in Brazilian Freshmen Students. Evolution: Education and Outreach, 3(1), 107-113. https://doi.org/10.1007/s12052-0090187-3

Setiawati, G. A. D. (2019). Kajian Miskonsepsi dalam Materi Fotosintesis dan Respirasi Tumbuhan Pada Mahasiswa Jurusan Pendidikan Biologi Universitas Pendidikan Ganesha Tahun Pelajaran 2010/2011. Jurnal Biologi Konstektual (JBK), 1(2 SE-Articles). Retrieved from http://ejournal.unmas.ac.id/index.php/JBK/arti cle/view/630

Tayubi, Y. R. (2005). Identifikasi Miskonsepsi Pada Konsep-Konsep Fisika Menggunakan Certainty of Response Index (CRI). Jurnal Mimbar Pendidikan, 24(3), 4-9. 